DOI $10.14746 / \mathrm{ssp} .2020 .4 .1$

Faustyna MiJalska

Adam Mickiewicz University in Poznań

ORCID: 0000-0002-9650-8719

Jarosław KARDAŚ

Adam Mickiewicz University in Poznań

ORCID: 0000-0002-1517-6215

\title{
The Basis of Social Protests in Georgia in 2019
}

\begin{abstract}
Coming to power in 2012, the Georgian Dream promised changes expected by Georgian society that was torn between striving for peace and prosperity, following the example of Western countries, and stabilizing relations with Russia. After seven years, this promise was not fulfilled, and the citizens were bitter about the internal and international policies of Bidzina Ivanishvili. For the purpose of this article, the research hypothesis was formulated that in June 2019 social protests broke out in the capital of Georgia, because the activities of the party headed by Bidzina Ivanishvili resulted in decreased social confidence in this formation. The authors of the article analyzed the activities of Bidzina Ivanishvili which might have sparked social unrest and identified the internal and external factors that resulted in the shrinking social confidence in Georgian authorities in recent years. The authors presented also the events of June 20, 2019, when thousands of people gathered in front of the Georgian parliament building to express their discontent with the presence of the deputy of Russian Duma, Sergei Gavrilov, at the parliamentary session, which resulted in nationwide protests.
\end{abstract}

Key words: Georgia; social protests; Russia; new social movements; conflict

\section{Introduction}

The study of systemic transformation in Georgia is of the utmost importance for modern political science. Numerous political scientists argue that, after 2003, the phenomenon observed in Georgia was unique in the entire post-Soviet space. It was the only former Soviet republic that resolved to carry out a comprehensive political and economic reform. Introducing a number of changes in many fields was imperative as, at the end of the 20th century, Georgia was in fact a failed state. This was due to not only the conflicts in South Ossetia and Abkhazia, but also the civil war that broke out in this country in the early 1990s between the national- 
ist camp (headed by the first president of Georgia, Zviad Gamsakhurdia) and the former communist nomenclature (led by Eduard Shevardnadze) (Lazarus, 2010).

When the team of Mikheil Saakashvili came to power in Georgia (i.e. after the events that came to be called the Rose Revolution), they decided to pursue a new foreign policy (aiming at close integration with NATO and a consolidated alliance with the United States), and reform state institutions (Grodzki, 2009, p. 49). The involvement of the state in the economy was reduced, the tax system was simplified, bureaucracy was limited, and a large scale campaign against corruption and the shadow economy was launched. However, Mikheil Saakashvili's team failed to avoid making mistakes, as their government repeatedly abused power (Musiałowicz, 2008, pp. 87-88). When the United National Movement party was in power, the state apparatus was politicized, state officials enjoyed impunity, and political competition and independent judiciary were restricted (Matusiak, 2014). The tensions culminated in 2007, when an anti-presidential revolution broke out (called the Revolution of Birch-rods), leading to a state of emergency being introduced throughout the country and early presidential elections being held (which, however, resulted in Mikheil Saakashvili being re-elected) (Kuca, Grzybowski, 2012, p. 17).

In 2012-2013, after Mikheil Saakashvili's team lost the parliamentary and presidential elections, they lost power to the Georgian Dream party (Avaliani, 2019). Importantly, the change of power took place peacefully. It is worth noting, however, that Georgian Dream included a range of parties and groups with various political platforms, which were united only by their aversion (or even hostility) towards the then president of Georgia. Another factor binding smaller political entities was that they all acknowledged the leadership of Bidzina Ivanishvili, whose financial support made an effective campaign possible. In the next elections (be they parliamentary or presidential elections), Georgian Dream's mandate to exercise power kept being renewed. The question that arises then is what happened that made the Georgians oppose the policies of Ivanishvili's party in June 2019. The research hypothesis formulated for the purposes of this article is that the social protests in the capital of Georgia in June 2019 were staged because the activities of the group headed by Bidzina Ivanishvili (both on the domestic and international scene) had undermined public trust in this formation. The principal method used in the article is the decision method (used to examine the activities of Bidzina Ivanishvili), the systemic method (employed to indicate internal and ex- 
ternal factors that undermined social trust in the authorities in Georgia in recent years) and the institutional-legal method (applied when analyzing the provisions to amend the constitution).

\section{What are social movements?}

The strong protests of the Georgians against the policies and activities of the Georgian state authorities may seem to be a model example of a social movement that emerged as a democratic expression of social discontent. Social movements, including the protest in question, may concern numerous issues at the same time and pursue very different goals.

The scholarly literature indicates a number of functions that social movements perform, thereby confirming they are nowadays a muchneeded tool "in the hands" of citizens, and many researchers call the $21 \mathrm{st}$ century society "a society of social movements." The reasons for this include, among other things, mass education, traditional values becoming erratic, emphasis on development and activity, urbanization, the spontaneity of actions resulting from the specific anxiety of a large social group triggered by its material, political or ethnic situation, or even an ecological threat, and so on (Ekstowicz, 2015, p. 45).

Social movements influence public debate, determine the hierarchy of important matters, express interests, allow political entities to identify previously overlooked problems, influence legislation and public policies, and are sometimes responsible for rapid changes, coups or revolutions (Lipiński, 2012, p. 52; Della Porta, Diani, 2009, pp. 255-266). Social movements are highly voluntary and spontaneous, but also organized to some extent. Therefore, they are fundamentally different, on the one hand, from the activities of political parties and other organizations that are part of a formalized and established system of institutions, and, on the other, from riots, demonstrations or unrest that are merely a reflexive, chaotic and short-lived response to an event (Ruchy społeczne $P W N$ ).

Social movements are one of the most common forms of collective social activity. They adapt to the specific characters of various communities and social groups, their needs and interests, the foundations of their internal organization, stability and permanence, and their determination in pursuing goals. However, their complexity makes it difficult to agree on how to define them. They differ not only in size, the degree of formali- 
zation, the lawfulness of their activities, but also in the scope of activities, goals, and the fact that they arise and operate in various cultural or social contexts (Rozalska, 2015, p. 35).

Piotr Sztompka considers the following to be most important components of social movements: people acting together as a community; the goal of action which is defined by the movement members in a similar way; and the low level of formal organization of the community (dispersion), whose actions are spontaneous, non-institutionalized and unconventional (Sztompka, 2005, p. 256).

Mario Diani, on the other hand, approaches social movements as a separate social process. He identifies an element related to the concept of identification, whereby social movement members share a unique, inimitable collective identity which determines their individuality. According to Diani, it is a prerequisite for a social movement to develop and exist. He observes that social movement members, in addition to participating in a type of relations based on conflict (where the opponent is clearly defined), and being part of informal networks, have a separate, collective identity (Della Porta, Diani, 2009, pp. 23-25).

Sztompka believes that the sociological theory of social movements should be considered in a broader perspective of the analysis of social change (Nowosielski, 2014, p. 7). The fact that social movements influence change is emphasized by numerous studies on this issue. According to Bogdan Ekstowicz, it is justified to say that change is the principal goal of social movements. Starting with the relations between social movements and change, it is indicated that a social movement may contribute to or be caused by social change (it may be its cause or effect); may be future or past oriented; may pursue change or inhibit it; and aim to introduce changes quickly and at once, or opt for their gradual, slow introduction (Ekstowicz, 2015, pp. 45-48).

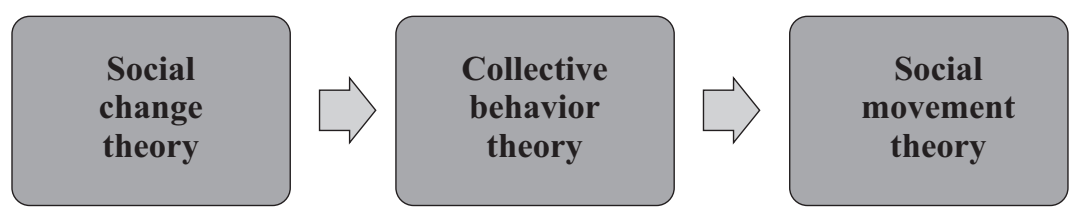

Figure 1. The position of social movement theory in the social change theory as seen by Sztompka

Source: Nowosielski M. (2014), Ruchy społeczne jako czynnik i wynik zmian społecznych, "Kultura i Edukacja", no. 4(90). 
One of the essential features of social movements is that they use protest to achieve their goals. Due to their spectacular nature, protests have often attracted the attention of researchers. Some of them argue that it is the use of protests as a strategic means of exerting influence that distinguishes social movements from other, often much more conventional, forms of participation (Mandes, 2007, pp. 8-10). Although sometimes protests are staged by single individuals, protests are essentially collective, sometimes mass actions.

What is the difference between a protest and a social movement? According to Piotr Matczak, the boundaries are blurred. Social protest, in its broadest sense, is a collective action of a social movement aimed at changing the system of political representation or the relations between citizens and the state in their entirety. Protest can therefore be treated as a "narrower" case of a social movement. Basically, social protest does not have an ideological dimension. It is assumed here that a protest is a certain event, whereas a social movement is an organizational form of social mobilization. Social movements may use protest as a strategy which may constitute the basis for the movement's crystallization. Matczak points out, however, that not every social movement uses protests to promote its solutions (Matczak, 2000, p. 151).

Today, social movements are seen as one of the principal collective actors behind social change. Citizens are more and more active in pursuing the common good, or in order to bring about a certain change. They can do this through collective action, for example through social movements. This was also the case with the June events in almost all of Georgia.

\section{Georgian Dream - a classical "ruling party"?}

From 2013, Bidzina Ivanishvili has been the main figure in Georgia's political life, initially as prime minister, and then operating behind the scenes (holding no significant state office), controlling Georgia's internal and foreign policies (Matusiak, 2014). Numerous analysts studying the political system in Georgia believe that any legislative, executive or judiciary body would not dare to make an independent decision without Ivanishvili's approval. As a result, the people in the highest state offices in Georgia are completely dependent on him. The party's leader's instrumental treatment of the politicians holding the position of prime minister is best evidenced by the fact that they have been changed three times 
since 2013. After Ivanishvili, who held this office in 2012-2013 (Tolksdorf, 2014, p. 14), Irakli Garibashvili, Giorgi Kvirikashvili and Mamuka Bakhtadze ${ }^{1}$ were successive prime ministers. Ivanishvili's political power is also demonstrated by his repeated criticism of President Giorgi Margvelashvili, who won the 2013 elections with the support of Georgian Dream. During his term in office, he tried to pursue policies independent from the ruling team, which resulted in an announcement issued by the Ivanishvili's formation one year before the upcoming presidential election that it would support a completely different candidate in that election. Due to this conflict, Giorgi Margvelashvili withdrew from political life after the end of his term.

The political platform of the coalition formed by Ivanishvili (for the parliamentary elections in 2012) was based on slogans proclaiming that the former authorities should be held accountable for their abuse of power, and that the liberal economic reforms launched when the United National Movement was in power require correction. Having won the elections, Georgian Dream introduced a number of changes in social policy. Citizens were provided with basic health insurance and the neo-liberal labor code whereby employers enjoyed huge rights at the expense of employees was abandoned. Pensions and disability allowances were also rapidly increased. Another important change included providing social protection for the unemployed. The decentralization of local governments also started (Matusiak, 2014). Bidzina Ivanishvili's party strengthened its position in the most recent parliamentary elections, held in autumn 2016. As a result, Georgian Dream won a constitutional majority in parliament. As many as 115 seats in a 150 -strong chamber were awarded to politicians from Georgian Dream. The remaining seats were taken by representatives of the United National Movement (27 seats) and the Alliance of Patriots of Georgia (6 seats) (the remaining two seats were taken by smaller parties) (Falkowski, 2016). One year after the elections (in October 2017), the ruling formation decided to adopt a new basic law, which introduced a parliamentary system in Georgia. This, in a way, completed the transition from the presidential system (provided for by the 1995 constitution) to a system in which the prime minister plays a key role. It should be noted, however, that the first steps in this direction were taken in 2010 (under the rule of the United National Movement), when the constitution was amended so

1 September 2019 saw yet another change in the office, since Mamuka Bakhtadze stepped down as the head of the government. 
as to strengthen the position of the head of government. This change was deliberately introduced by Mikheil Saakashvili, who was to be appointed prime minister after his second term as president. Interestingly, following the adoption of the new constitution, several members of Georgian Dream left the party, whereby the party lost its constitutional majority, although it still remained the strongest formation in Georgian parliament.

A survey of public attitudes demonstrates that Georgians are increasingly tired of the rule of Ivanishvili's party. In April 2019, support for this formation was at just over 20 percent (Political, 2019), which was a significant decrease compared to the 2016 election result (when Georgian Dream garnered almost 49 percent of votes). After several victories in a row (including the parliamentary elections in 2012 and 2016, and the 2013 presidential election), Georgian Dream did not have any candidate in the 2018 presidential election. Being aware of his party's dwindling support, Ivanishvili decided it would be better to support an independent candidate, Salome Zurabishvili. This decision was dictated solely by election rationale. In the event of a victory, the success would benefit Georgian Dream, whereas a defeat would be attributed only to the candidate herself. The independence of Salome Zurabishvili was highly debatable, however. Interestingly, until the day of the second round of the presidential election, the ruling camp was not sure of victory since in the first round Zurabishvili had a minimal advantage over her opponent - Grigol Vashadze (38.64 percent and 37.74 percent respectively) (Górecki, 2018b).

This uncertainty among the authorities as to the election result was caused by numerous citizens' disappointment with the fact the election promises had not been fulfilled. The unfulfilled promise to improve Georgia's economic situation was particularly difficult to bear. The paramount economic problems of this Caucasian republic include unemployment, low wages, depreciation of the national currency - the lari, and overall indebtedness. The World Bank also stressed the devaluation of the lari and the poor economic situation in its forecasts for Georgia (Prognozy, 2018). The 2015-2016 period in particular marked a major economic slowdown in this country. At that time, GDP was at the level of 2.9-2.8 percent. It was only in the last two years that the GDP has increased to 4.7 percent. Another issue is the large number of the unemployed in the labor market. In 2018, the unemployment rate was almost 13 percent. Although the Georgian Dream government managed to curb it, for example as compared to 2013, when it was almost 17 percent (Main, 2018), the unemployment rate continues to be one of the biggest problems of the 
Georgian economy. Inflation in 2018 was 4.6 percent (Gruzja - wskaźniki ekonomiczne..., 2019). The significance Georgian voters assign to the improvement in the quality of life is demonstrated by the fact that Salome Zurabishvili managed to win the 2018 presidential election largely due to Prime Minister Mamuka Bakhtadze's announcement that he would do his best to pay off the bank loans of several hundred thousand people (Górecki, 2019). Public opinion polls indicate that Georgian citizens suffer from economic problems to the greatest extent. This is very clearly demonstrated in a poll carried out by the Caucasus Research Resource Center for the National Democratic Institute in June 2018, and in a study carried out by the Center for Insights in Survey Research in September and October 2019. Examining the results of the former, one can see that economic issues are the most important problems that were not solved in Georgia in the last decade.

\section{Graph 1. Which areas of life have changed in Georgia in the last 10 years?}

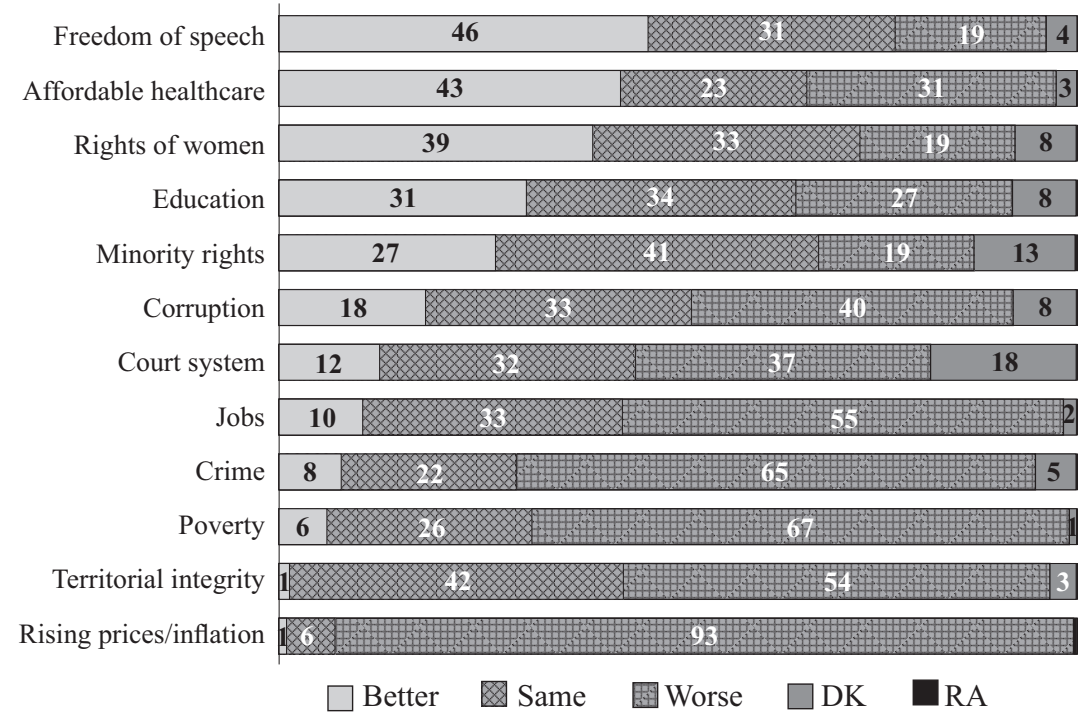

Source: Public attitudes in Georgia, Caucasus Research Resource Center, 2018, https:// www.ndi.org/sites/default/files/NDI_June_2018_Presentation_Public_ENG_vf.pdf.

Similar conclusions can be drawn from the 2019 survey by the Center for Insights in Survey Research. In this poll, conducted on a group of 1,500 Georgians, they answered the question concerning the most impor- 
tant problems of contemporary Georgia - and most frequently indicated unemployment, the cost of living, high prices and poverty.

\section{Graph 2. What is the most important problem facing Georgia today? (up to two responses permitted)}

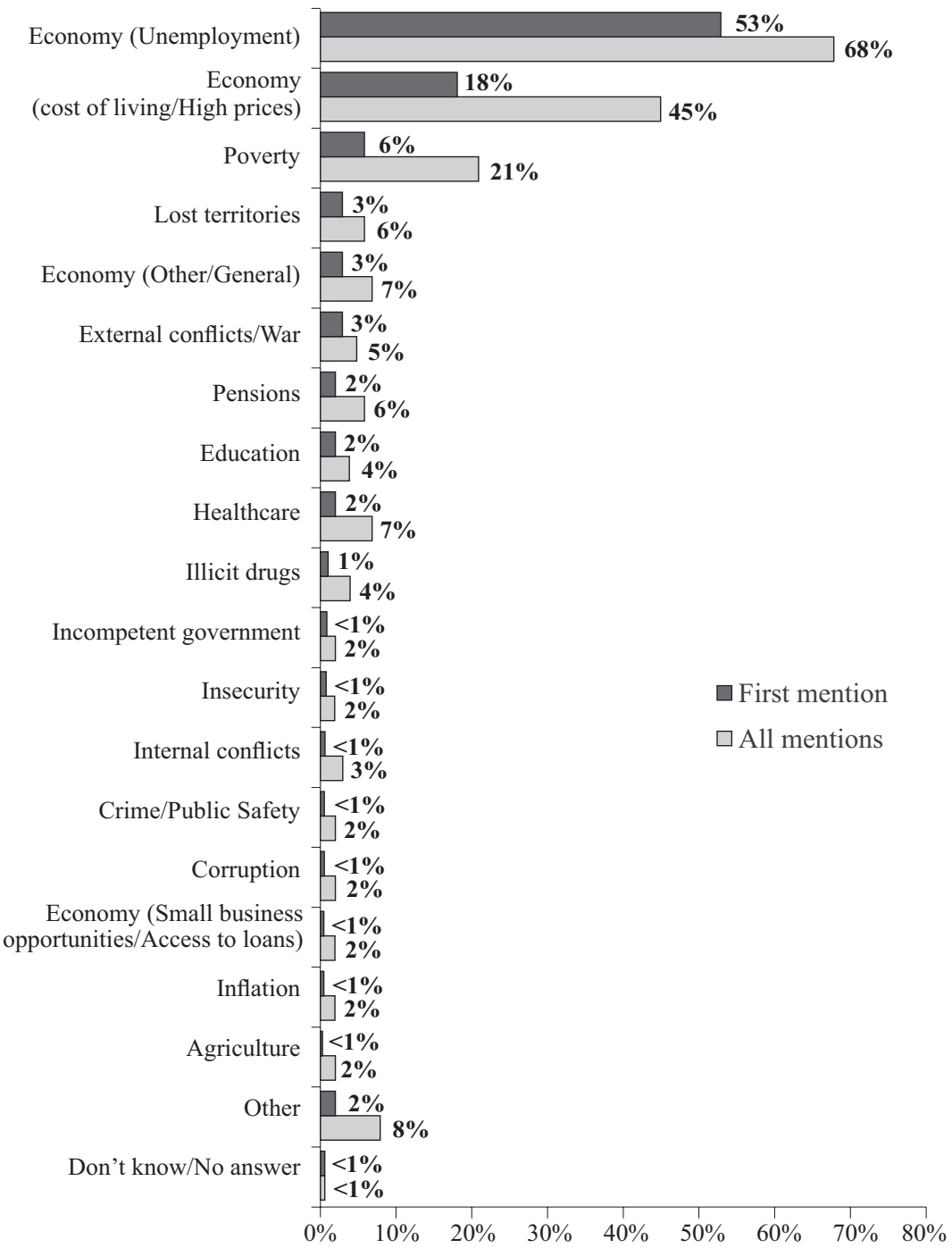

Source: Public Opinion Survey: Residents of Georgia, Center for Insights in Survey Research, 2019, https://www.iri.org/sites/default/files/georgia_poll_2.pdf. 
Over time, Georgian Dream began to make mistakes that were typical of many governing parties operating in the former USSR countries. This is confirmed by the recently deteriorating assessments of the state of democratization in Georgia in the annual Freedom House rankings. In the 2017 report, Georgia's result was lower than that in 2016 (Wojtasiewicz, $2018 b$ ). The report strongly criticizes the fact that the person who in fact has the greatest influence on political decisions does not hold any prominent offices (prime minister or president). According to the authors of the document, it is disturbing that these offices are held by former business partners of the billionaire. The authors are also concerned about the fact that state bodies are being used to prosecute and repress politicians associated with the group that was in power in 2003-2012. In recent years, the offices of the United National Movement have also been frequently damaged during various election campaigns. Such incidents took place, for example, before the local elections in May 2016 or the parliamentary elections in October 2016 (Falkowski, Strachota, 2016). The premises of this formation were also wrecked in the fall of 2015, when a campaign was launched that attempted to discredit the politicians of the United National Movement. The recordings of prisoners being tortured during the rule of the United National Movement came to light at that time. In many Georgian cities, street protests were organized (inspired by the Georgian Dream politicians) to demand that the formation of Mikheil Saakashvili be banned (Falkowski, 2015). In addition, Freedom House analysts believe that the judiciary is increasingly dependent on the executive in Georgia (Freedom, 2017). One of the arguments supporting this observation is the reform of the judiciary launched in 2018. As a result of this reform, Supreme Court judges are appointed by the Supreme Council of Justice, instead of the president, and then approved by parliament. Much controversy was also caused by the resignation of the Chairperson of the Supreme Court, Nino Gvenetadze. The official reason was her health issues, but many independent analysts believe she was forced to resign (Freedom, 2019).

It is also worth noting that, from time to time, recordings have come to light which are supposed to show various types of wrongdoing committed by the ruling team. The tapes published during the 2018 presidential campaign by Rustawi 2 television (i.e. by the main opposition station) strongly resonated; they illustrated how high-level state officials were illegally remunerated and how the Georgian Dream party was illegally financed (Wojtasiewicz, 2018a). In May 2019, the same television station revealed 
recordings of one of the city councilors (from the ruling party) in Zugdidi saying that the leadership of Georgian Dream demanded that their party should win the election for the city mayor at any expense. All these factors result in declining public support for Bidzina Ivanishvili's formation.

Georgian society is disappointed both with the activities of the present authorities and with the opposition. This is well demonstrated by the reactions of protesters in June 2019 to the speeches of the United National Movement representatives (the description of these events follows below). Although the opposition supported the protests, it tried not to participate in them actively, as the demonstrators booed its representatives (Górecki, 2019). A large part of society still remembers how the United National Movement abused its power. Mikheil Saakashvili himself has a poor reputation and his returning to the internal political game is out of the question. In June 2018, he was sentenced to six years in prison for abuse of power and concealing the evidence of the beatings of opposition MP Valery Gelashvili, which occurred when he was head of state. It is worth noting that this was not Saakashvili's first conviction. A few months earlier (in January 2018), the Tbilisi City Court sentenced him in the first instance to three years in prison and banned him from holding public offices. The justification stated that during his presidency Saakashvili exceeded his powers and committed numerous abuses (Górecki, 2018). Although Saakashvili has been living abroad since the 2013 presidential election, he tried to influence the United National Movement. However, opposition to the former president was growing inside the party, which led to a rift inside this party at the beginning of 2017. Its leadership was assumed by three politicians - David Bakradze, Giga Bokeria and the former mayor of Tbilisi, Gigi Ugulava. The defeat in the 2016 parliamentary elections contributed to this change. As a result of this rift, as many as 20 deputies left the 27-person faction of the United National Movement (Falkowski, 2017a).

\section{All quiet on the Western/Eastern front}

Georgian society is disappointed with the activities of the current political elite, not only on the domestic but also on the international scene. Georgians are concerned about the fact that the process of integration with the West is in fact stalled, and that relations with Russia are becoming increasingly tense. 
According to a 2018 survey by the Center for Insights in Survey Research, when asked about Georgia's relations with selected countries, the vast majority of respondents -89 percent - assessed relations with Russia as bad.

\section{Graph 3. How would you characterize the current state of the relationship between Georgia and the following countries? [in \%]}

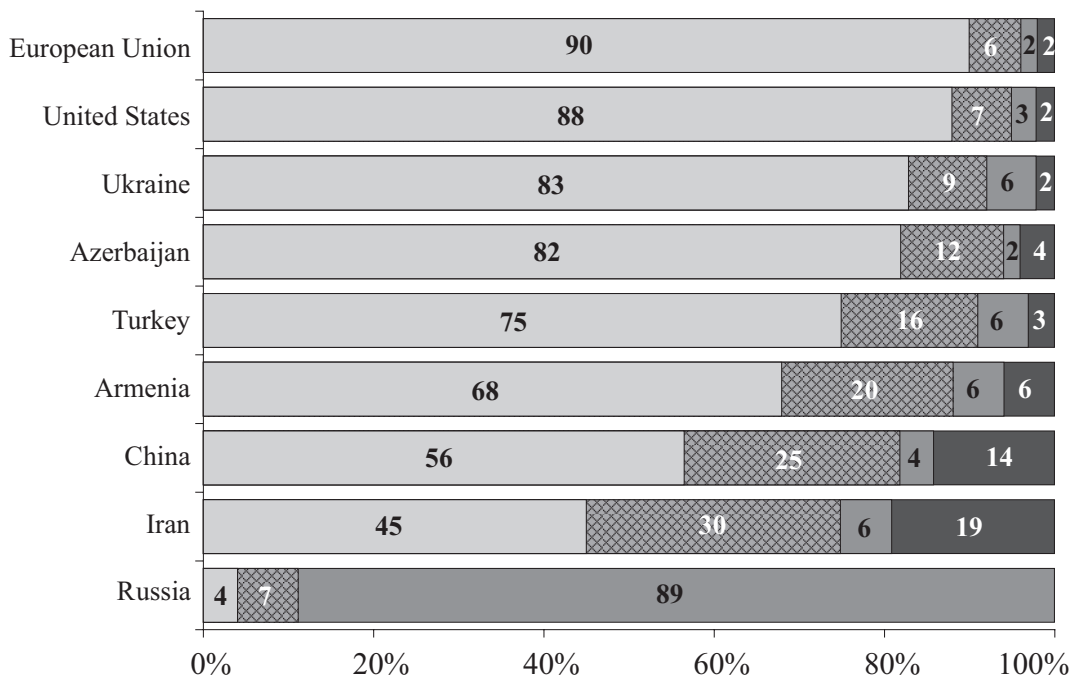

$\square$ Good $\quad$ Neither good nor bad $\square$ Bad $\square$ Don’t know/No answer

Source: Public Opinion Survey: Residents of Georgia, Center for Insights in Survey Research, 2018, www.iri.org/sites/default/files/2018-5-29_georgia_poll_presentation.pdf.

Relations between Georgia and Russia have been strained since the war in 2008 (after Russia invaded South Ossetia). Before Russia imposed an economic embargo on Georgia in 2006, Russia was the main recipient of Georgian exports. When the Georgian Dream coalition took power in Tbilisi in 2012, the new government revised Mikheil Saakashvili's policy to Russia, seeking to correct the mistakes made by its predecessors. Georgian Dream began to normalize relations between the two countries. The Georgian authorities welcomed Russia's decision to ease sanctions against Georgia shortly after the 2012 elections.

Georgian-Russian relations have been discussed in various contexts on the political level for years. Although talks have been held in Geneva for ten years, they have not brought about any political breakthrough. 
The positions of both parties have been set in advance and are unlikely to change in the foreseeable future. The situation is further complicated by the fact that Russia does not acknowledge its responsibility for the conflicts in Georgia and officially takes a neutral position (Kojava, 2018). The Kremlin argues that the events of 2008 were "a humanitarian intervention intended to prevent genocide in North Ossetia" (Van Herpen, 2014 , p. 358). Meanwhile, the Georgian opposition has accused the present government of making concessions to Russia and believes that governmental actions cannot solve the problem of territorial integrity.

Over the past few years, Russia has become a major export market for Georgian products, especially wines and agricultural products. The number of Russian tourists in Georgia has also grown rapidly. In 2018, 1.4 million Russians visited Georgia, and tourism accounted for almost 8 percent of its GDP (Kakachia, Lebanidze, 2019). Nevertheless, after the events of June 2019, the Kremlin realized that its soft power (including access to the Russian market, interpersonal contacts, and common religion) had failed. Some experts are of the opinion that Russia's attempts to normalize relations with Georgia are a direct result of the armed conflict in Ukraine. Moscow may seem to be trying to find common ground with Tbilisi in order to avoid tensions with another post-Soviet republic (Sikharulidze, 2017).

Georgian society is becoming increasingly polarized. It is a definite political challenge for Georgian Dream that Georgians, who appreciate the reforms implemented since 2003 (e.g. an effective campaign against corruption, restoring the functionality of state institutions, etc.), also have high expectations about the improvement of their material situation. Interestingly, these expectations are related to European integration (Falkowski, 2017b). The Georgian authorities have perceived the successive stages of getting closer to the European Union and NATO as leading to the ultimate goal of accessing both organizations. ${ }^{2}$ The pro-Atlantic attitude of the Georgian population has so far coincided with the attitudes expressed at NATO summits. Members of the North Atlantic Pact have been encouraging Georgians to persevere and maintain a pro-Western course, while failing to meet their main expectation. In March 2019, the NATO Secretary General Jens Stoltenberg said during his visit in Tbilisi that Georgia had made significant progress towards Euro-Atlantic inte-

${ }^{2}$ Georgia's NATO membership would aggravate tensions in bilateral relations with Russia. Such a decision would probably make Moscow increase its military presence in the separatist republics and its armed forces would enter the north of Georgia. 
gration and would certainly become a member of the alliance; however, he did not specify when this could happen and whether Georgia could join NATO without Abkhazia and South Ossetia.

The website of the European Council states that the EU supports Georgia's efforts to strengthen mutual relations. The parties are deepening their mutual political association and economic integration. The Association Agreement and Comprehensive Free Trade Area between the EU and Georgia are fully in force as of July $1,2016 .{ }^{3}$ In 2017, the EU was Georgia's key trading partner, accounting for 27 percent of its total trade. In a report on Georgia's implementation of the visa liberalization action plan, in December 2015, the European Commission stated that the country had complied with the EU's visa waiver requirements (these criteria include, among other things, introducing biometric passports, improved border protection, combating corruption, organized crime and terrorism, as well as police cooperation with the EU). As a result, Georgian citizens have been able to travel without visas to the Schengen area since March 28, 2017 (Ochman, 2018). The EU supports the territorial integrity of Georgia and its attempts to resolve the conflict in Georgian separatist regions: Abkhazia and South Ossetia. The EU's commitment involves participation in the international talks in Geneva, co-chaired by the EU Special Representative, and a monitoring mission in Georgia (Stosunki, 2018).

Yet, at present, many Georgians feel disappointed with the lack of support from Western Europe and the United States. For decades, Georgian citizens have cultivated a sense of bond with European civilization, hence the emotional nature of Georgian-European relations (Grajczyński, 2018). When the center-left Georgian Dream took power, the policy of the state to the West did not change profoundly (even though the party had been perceived as having a positive attitude towards Russia until then). A survey conducted by the National Democratic Institute in December 2018 indicated that 83 percent of Georgian citizens supported the idea of European Union membership, but in 2019 this number dropped to 77 percent. The opponents of the rapprochement with the EU argue that "it may trigger a conflict with Russia" (39 percent) (Gruzja nie jest gotowa...).

A Russian provocation or Georgian oversensitivity?

On June 20,2019, a crowd of thousands gathered in front of the Georgian parliament building. They were outraged by the appearance

\footnotetext{
${ }^{3}$ The agreement was applied provisionally from September 1, 2014.
} 
of a deputy of the Russian Duma, Sergei Gavrilov, at the parliamentary session. Russia had sent its delegation to Tbilisi to participate in the Interparliamentary Assembly on Orthodoxy. ${ }^{4}$ Gavrilov spoke in Russian, having taken the place of Irakli Kobakhidze, Speaker of the Georgian parliament (Kacewicz, 2019). Before this visit, Georgian opposition forces had protested against Gavrilov paying several visits to South Ossetia and Abkhazia (Georgia's, 2019). The protesters in Georgia were concerned about the ruling party's increasingly close relations with Russia. Although Georgian citizens take advantage of better economic relations with Moscow, the pursuit of closer political ties has proved unpopular with Georgians.

During the events of June 2019, over 240 people were injured (including around 80 policemen), and around 300 were arrested in the clashes outside the Georgian parliament on the first day of the protests. The police used tear gas and rubber bullets. The number of casualties rose slightly in the following days. The images of bloody faces were broadcast by television stations all over the world. President Salome Zurabishvili and Prime Minister Mamuka Bakhtadze had to shorten their visits abroad (Georgia's, 2019). The protests against the Russian addressing the parliament were simultaneously staged in Batumi and Gori, as well as elsewhere (Russian, 2019). Some protesters held banners condemning Russia and the Russian President Vladimir Putin.

It should be mentioned that both the Speaker of Parliament Irakli Kobakhidze and Prime Minister Bakhtadze stated that it was "very difficult" to see a Russian politician sitting in the chair in the Georgian parliament. The chairman of the Georgian Dream party, Bidzina Ivanishvili, declared that he was as indignant as the overall public. He added that a representative of the occupant state should not be allowed to chair any forum in the Georgian parliament. It was a protocol error the political significance of which had not been realized by the organizers (Thousands, 2019).

Nevertheless, opposition party leaders demanded during the protest that the Georgian Parliament Speaker Irakli Kobakhidze, the Interior Minister Giorgi Gakharia and the head of the state security service Vakhtang Gomelauri step down. The protesters did not offer any feasible solutions whereby the territory controlled by separatists since the 1990s could be recovered. However, they demanded that a fully proportional elec-

${ }^{4}$ The IA has operated since the early 1990s. It is currently chaired by Sergey Gavrilov, a representative in the Russian Duma and a member of the Communist Party, who had voted for the independence of Abkhazia and South Ossetia from Georgia. 
toral system ${ }^{5}$ be introduced in the parliamentary elections in 2020, and that early parliamentary elections be organized (according to the election calendar, they were scheduled for autumn 2020). Ivanishvili's announcement that the proportional electoral system would be introduced in 2020, instead of 2024, and that the electoral threshold would be abandoned was considered a partial victory by the protesters on June 24 (Wojtasiewicz, 2019). Some real estate owners in Georgia started to raise fees for various services rendered to Russian customers by 20 percent, explaining that Russia occupied 20 percent of Georgia's territory. This was likely to trigger a response from Russia. The Kremlin denounced the protests as a "Russophobic provocation," while the Russian Foreign Ministry accused the Georgian opposition of trying to prevent an improvement in bilateral relations. Among other things, Moscow suspended air traffic between the two countries, justifying its decision with concerns about the safety of Russian citizens. Georgia is a popular destination for Russian tourists. After the rallies in the streets of Tbilisi, the Kremlin stated that the internal ban was to "ensure national security to Russia and protect Russian citizens from criminal and other unlawful activities" (Crowds, 2019). Interestingly, President Vladimir Putin called on the government to take measures to ensure the return of Russian citizens who were temporarily on Georgian territory (Kucera, 2019). This time the Russian government attacked an important industry in Georgia - the tourism sector.

Foreign diplomats, artists, athletes and ordinary individuals called on the international community to visit Georgia and supported the social media campaign under the hashtag \#SpendSummerInGeorgia. The Georgian Orthodox Church called on its parishioners to spend their summer vacations in Georgia and requested that the banking industry ease the obligations of borrowers to help the troubled tourism industry.

The Russian Federation also hindered the export of certain products from Georgia. ${ }^{6}$ For example, on June 24, 2019, the Russian Consumer Protection Agency announced that Georgian wine exports to Russia (which were estimated by some to amount to 50 million bottles in 2018)

${ }^{5}$ As stipulated in the latest amendment to the constitution, this is to happen in 2024. At present, 77 out of 150 deputies are elected from party lists in a proportional system, and 73 in single-member constituencies, which gives an advantage to the largest parties, including especially the ruling party.

${ }^{6}$ Russia imposed a similar form of political pressure on Georgia in 2006. In the past, Russia closed its borders to Lithuanian dairy products, Tajik nuts and Ukrainian chocolate confectionery. 
and exports of the popular Borjomi mineral water fell significantly after the protests. Quality controls intensified, which resulted in some consignments of Georgian wine being held at customs (Luxmoore, 2019).

Perhaps Georgian Dream believed that a friendlier attitude would lead to concessions from Russia in the territorial conflict. However, no concessions were made, and now this formation is paying a high price for its foreign policy.

\section{Conclusion}

The events of June 2019 demonstrate that Georgians have grown weary of the nearly seven years of Georgian Dream's being in power. The material situation of many Georgian citizens has not improved, and every month new facts come to light that show that the authorities are abusing power. It is clearly visible that Georgians are experiencing a specific deja $v u$, because the situation was similar towards the end of the United National Movement's being in power. Importantly, the political crisis of June 2019 has undermined the two foundations of Georgian Dream's authority. Firstly, the belief that the present government does not use violence against citizens who protest against its actions has been shattered. Secondly, it has been noted that all the statements about rational foreign policy (aimed at avoiding conflicts with the Russian Federation) have not translated into facts. The use of force during the June events and the lack of clear directions for Georgia to pursue have seriously undermined Georgian Dream's maintaining power. The parliamentary election is next year and it may give the public an opportunity to pull out the red card for the current ruling party and the opposition. The emergence of a new entity on the Georgian political scene being able to seize power cannot be ruled out. The cases of Armenia and Ukraine (where politicians who were independent from the current political formations, such as Nicol Pacinian and Volodymyr Zelensky, came to power in the last two years) show that such a scenario cannot be ruled out in Georgia either.

\section{Bibliography}

Avaliani D. (2019), Georgian Dream Is Dealt a Double Blow, https://carnegie.ru/ commentary/79369, 27.06.2019. 
Crowds try to storm Georgian parliament in Tbilisi (2019), www.dw.com/en/crowdstry-to-storm-georgian-parliament-in-tbilisi/av-4929032, 26.06.2019.

Della Porta D., Diani M. (2009), Ruchy społeczne. Wprowadzenie, Kraków.

Ekstowicz B. (2015), Procesy i ruchy społeczne na świecie na przełomie XX i XXI wieku, "Civitas Hominibus", no. 10.

Falkowski M. (2016), Cała władza w ręce Gruzińskiego Marzenia, https://www.osw. waw.pl/pl/publikacje/analizy/2016-11-09/cala-wladza-w-rece-gruzinskiego-marzenia, 27.08.2019.

Falkowski M. (2015), Kryzys polityczny w Gruzji, https:/www.osw.waw.pl/pl/publikacje/analizy/2015-10-28/kryzys-polityczny-w-gruzji, 28.08.2019.

Falkowski M. (2017a), Rozłam w gruzińskiej opozycji, https://www.osw.waw.pl/pl/ publikacje/analizy/2017-01-18/rozlam-w-gruzinskiej-opozycji, 28.08.2019.

Falkowski M. (2017b), UE-Gruzja: zniesienie wiz i co dalej?, https:/www.osw.waw. pl/pl/publikacje/analizy/2017-03-29/ue-gruzja-zniesienie-wiz-i-co-dalej?fbcl id=IwAR0MEgVEUuPMjZTiW8kX4jOhPaPT4xie2Gs5-vjWvhB3EiCgY67 d09w0Udk, 21.07.2019.

Falkowski M., Strachota K. (2016), Gruzja: Przedwyborcza niepewność, https:// www.osw.waw.pl/pl/publikacje/analizy/2016-09-28/gruzja-przedwyborcza-niepewnosc, 28.08.2019.

Freedom house criticizes former Georgian PM Bidzina Ivanishvili (2019), https:// www.georgianjournal.ge/politics/35579-freedom-house-criticizes-formergeorgian-pm-bidzina-ivanishvili.html, 29.08.2019.

Freedom in the World 2017 (2017), https://freedomhouse.org/report/freedomworld/2017/georgia, 29.08.2019.

Georgia's Russia protest benefit Mikheil Saakashvili (2019), www.dw.com/en/georgias-russia-protests-benefit-mikheil-saakashvili/a-49302532, 26.06.2019.

Górecki W. (2018a), Gruzja: kontrowersyjny wyrok na Saakaszwilego, https://www. osw.waw.pl/pl/publikacje/analizy/2018-01-10/gruzja-kontrowersyjny-wyrok-na-saakaszwilego, 29.08.2019.

Górecki W. (2019), Gruzja: napięcia wewnętrzne i nowy kryzys w stosunkach z Rosja, https://www.osw.waw.pl/pl/publikacje/analizy/2019-06-26/gruzja-napieciawewnetrzne-i-nowy-kryzys-w-stosunkach-z-rosja, 29.08.2019.

Górecki W. (2018b), Salome Zurabiszwili nowym prezydentem Gruzji, https://www. osw.waw.pl/pl/publikacje/analizy/2018-11-29/salome-zurabiszwili-nowym-prezydentem-gruzji, 27.08.2019.

Grajczyński P. (2018), Ciężar Kaukazu: geopolityczna sytuacja Gruzji, www.jagiellonia.org/ciezar-kaukazu-geopolityczna-sytuacja-gruzji/, 21.07.2019.

Grodzki R. (2009), Wojna gruzińsko-rosyjska 2008. Przyczyny - przebieg - skutki, Zakrzewo.

Gruzja - wskaźniki ekonomiczne (2019), https://pl.tradingeconomics.com/georgia/ indicators, 30.08.2019. 
Gruzja nie jest gotowa na wstapienie do Unii Europejskiej? (2019), https://pl.sputniknews.com/swiat/2019052010423491-sputnik-gruzja-nie-jest-gotowa-na-wstapienie-do-unii-europejskiej/, 22.07.2019.

Kacewicz M. (2019), Tbilisi: kolejna odsłona niedokończonych rewolucji, www. belsat.eu/pl/news/tbilisi-kolejna-odslona-serii-niedokonczonych-rewolucji/, 25.06.2019.

Kakachia K., Lebanidze B. (2019), Georgian Dream Meets Georgian's Nightmares, https:/foreignpolicy.com/2019/06/25/georgian-dream-meets-georgias-nightmare/, 26.06.2019.

Koiava R. (2018), Georgian - Russian Relations: Past, Present \& Future, https:// emerging-europe.com/georgia-2017/georgian-russian-relations-past-presentfuture/, 2.07.2019.

Kuca G., Grzybowski M. (2012), System konstytucyjny Gruzji, Warszawa.

Kucera J. (2019), Putin orders Russian tourists out of Georgia after anti-Russia protests, www.eurasianet.org/putin-orders-russian-tourists-out-of-georgia-afteranti-russia-protests-in-tbilisi, 27.06.2019.

Lazarus J. (2010), Neo-liberal State Building and Western 'Democracy Promotion': the case of Georgia, http://eisa-net.org/be-bruga/eisa/files/events/stockholm/ Neo-liberal $\% 20$ state $\% 20$ building $\% 20$ and $\% 20$ democracy $\% 20$ promotion $\% 20$ in\%20Georgia.pdf, 28.06.2019.

Lipiński A. (2012), Między komunikacja a kontestacja, Kultura, ramy interpretacyjne i ruchy społeczno-polityczne, ,Studia Politologiczne”, vol. 25.

Luxmoore M. (2019), As Georgia's relations with Russia sour Moscow says its wine has too, www.rferl.org/a/as-georgia-s-relations-with-russia-sour-moscowsays-its-wine-has-too/30019577.html, 28.06.2019.

Main Economic Indicators (2018), http://www.economy.ge/?page=ecoreview\&s=37, 30.08.2019.

Mandes S. (2007), Ruchy społeczne w Polsce, in: Wymiary życia społecznego. Polska na przełomie XX i XXI wieku, ed. M. Marody, Warszawa.

Matczak P. (2000), Protest lokalny w Polsce, "Ruch Prawniczy, Ekonomiczny i Socjologiczny", Year LXII - brochure 3.

Matusiak M. (2014), Gruzja - między marzeniem a rzeczywistościa, https://www. osw.waw.pl/pl/publikacje/komentarze-osw/2014-04-16/gruzja-miedzy-marzeniem-a-rzeczywistoscia, 27.06.2019.

Musiałowicz B. (2008), Gruzja - wybrane problemy polityki wewnętrznej i zagranicznej, in: Region Kaukazu w stosunkach międzynarodowych, eds. K. Iwańczuk, T. Kapuśniak, Lublin.

Nowosielski M. (2014), Ruchy społeczne jako czynnik $i$ wynik zmian społecznych, "Kultura i Edukacja”, no. 4(90).

Ochman K. (2018), Gruzja z silnym wsparciem UE $i$ nowymi umowami wartymi milion euro, https:/www.euractiv.pl/section/polityka-zagraniczna/news/gr- 
uzja-z-silnym-wsparciem-ue-i-nowymi-umowami-wartymi-miliony-euro/, 22.07.2019.

Political Ratings in NDI-Commissioned Poll - April 2019 (2019), https://civil.ge/archives/306143, 23.07.2019.

Prognozy Banku Światowego dla gospodarki Gruzji (2018), https://studium.uw.edu. pl/prognozy-banku-swiatowego-dla-gospodarki-gruzji/, 30.08.2019.

Public attitudes in Georgia (2018), https://www.ndi.org/sites/default/files/NDI June_2018_Presentation_Public_ENG_vf.pdf, 19.07.2019.

Public Opinion Survey: Residents of Georgia (2018), www.iri.org/sites/default/ files/2018-5-29_georgia_poll_presentation.pdf, 23.07.2019.

Public Opinion Survey: Residents of Georgia (2019), https://www.iri.org/sites/default/files/georgia_poll_2.pdf, 20.07.2019.

Rozalska A. (2015), Ruchy społeczne a potrzeba zmian w społeczeństwie obywatelskim. Podstawowe zagadnienia teoretyczne, "Uniwersyteckie Czasopismo Socjologiczne", no. 12(3).

Ruchy społeczne PWN, https:/encyklopedia.pwn.pl/haslo/ruchy-spoleczne;3969808. html, 31.03.2020.

Russian MP's appearance in Georgian parliament sparks protests across Georgia (2019), https://oc-media.org/russian-mp-s-appearance-in-georgian-parliament-sparks-protests-across-georgia/, 27.06.2019.

Sikharulidze A. (2017), Analysis. Russian - Georgian diplomatic relations - to be or not to be?, www.oc-media.org/russian-georgian-diplomatic-relations-to-beor-not-to-be/, 28.06.2019.

Stosunki UE - Gruzja (2018), https://www.consilium.europa.eu/pl/policies/eastern-partnership/georgia/, 28.06.2019.

Sztompka P. (2005), Ruchy społeczne - struktury in statu nascendi, in: Socjologia. Lektury, eds. P. Sztompka, M. Kucia, Kraków.

Thousands clash with police as protesters try to storm Georgian parliament (2019), www.oc-media.org/thousands-clash-with-police-as-protesters-try-to-stormgeorgian-parliament/, 27.06.2019.

Tolksdorf D. (2014), The EU, Russia and the Eastern Partnership: What Dynamics under the New German Government?, https://www.ifri.org/en/publications/ enotes/notes-cerfa/russia-and-eastern-partnership-what-dynamics-undernew-german, 27.08.2019.

Van Herpen (2014), Wojny Putina. Czeczenia, Gruzja, Ukraina 2014, Warszawa.

Wojtasiewicz W. (2019), Gruzini protestuja przeciwko Rosji, http://www.new.org. pl/6088-gruzini-protestuja-przeciwko-rosji, 2.07.2019.

Wojtasiewicz W. (2018a), Gruzińskie Sowa i Przyjaciele, http://www.new.org.pl/ 5839-gruzinskie-sowa-i-przyjaciele, 29.08.2019.

Wojtasiewicz W. (2018b), Powrót Iwaniszwilego, http://www.new.org.pl/5751-powrot-iwaniszwilego, 29.08.2019. 


\section{Podłoże protestów społecznych w Gruzji w 2019 roku}

\section{Streszczenie}

Gruzińskie Marzenie dochodząc do władzy w 2012 r. było obietnicą zmian, których oczekiwało społeczeństwo gruzińskie, rozdarte pomiędzy dążeniami do pokoju i dobrobytu wzorem państw zachodnich, a zarazem ustabilizowania stosunków z Rosją. Po siedmiu latach okazało się, że ta obietnica nie spełniła się, a obywatele są rozgoryczeni prowadzeniem polityki zarówno wewnętrznej, jak i międzynarodowej przez Bidzinę Iwaniszwilego. Na potrzeby artykułu sformułowano hipotezę badawczą zakładającą, że w czerwcu 2019 r. doszło do protestów społecznych w stolicy Gruzji, ponieważ działania podejmowane przez ugrupowanie kierowane przez Bidzinę Iwaniszwilego doprowadziły do spadku zaufania do tej formacji. Autorzy artykułu podjęli się próby analizy działań podejmowanych Bidzinę Iwaniszwilego, które mogły doprowadzić do niepokojów społecznych oraz wskazania czynników wewnętrznych i zewnętrznych, które doprowadziły do spadku zaufania do rządzących Gruzją w ostatnich latach. Ponadto przedstawili wydarzenia z dnia 20 czerwca 2019 r., kiedy to wielotysięczny thum zgromadził się pod budynkiem gruzińskiego parlamentu, by wyrazić niezadowolenie z pojawienia się na sesji parlamentu deputowanego rosyjskiej dumy, Siergieja Gawriłowa, co w rezultacie wywołało ogólnopaństwowe protesty.

Słowa kluczowe: Gruzja, protesty społeczne, Rosja, nowe ruchy społeczne, konflikt 
